\title{
Kontribusi Dakwah Bil Qalam Syaikh Nawawi Al-Bantani terhadap Nasionalisme Pesantren
}

\author{
Adeni \\ Fakultas Dakwah dan Komunikasi \\ UIN Walisongo Semarang \\ Email: adeni@walisongo.ac.id

\section{Silviatul Hasanah} \\ Fakultas IImu Tarbiyah dan Keguruan \\ UIN Walisongo Semarang \\ Email: silviatulh@walisongo.ac.id
}

\author{
Article Information \\ Submitted December 9, 2019 \\ Revision May 1, 2020 \\ Accepted June 11, 2020 \\ Published July 30,2020
}

\begin{abstract}
The study aims to examine the contribution of Shaykh Nawawi al-Bantani to the formation of pesantren nationalism through the preaching of bil qalam. The method used is a qualitative method by exploring the works of Shaykh Nawawi al-Bantani, especially those relating to jihad in the national context reflecting the attitude of nationalism, and by seeing their contribution to the world of pesantren. The results of the study showed that Shaykh Nawawi alBantani preached with bil qalam approach, namely in the form of intellectual jihad. He was not directly involved in physical resistance against the invader. But it instilled the enthusiasm and awareness of the love of the motherland in each of his students. Nawawi's work was then taught in the world of pesantren, especially NU pesantran. Scholars like KH. Hasyim Asy'ari, who was influenced by Nawawi's struggle, built the NU organization that not only appeared as the most significant Islamic mass organization but also contributed to the initial formation of the Indonesian national identity. It can be seen from the involvement of $\mathrm{KH}$. Wahid Hasyim in the 1945 BPUPKI-PPKI session. It shows that NU has the same Islamic orientation as what Syaikh Nawawi thought. Nawawi's moderate and contextual attitude always colors NU's actions in carrying out religious propaganda and national propaganda in Indonesia. This also proves that santri is not just a religious entity that lives in Indonesian society, but at a crucial point, santri is the identity of the Indonesian people themselves
\end{abstract}

\section{Keywords:}

Bil Qalam, Nawawi al-Bantani, Nationalism, Indonesian-ness 
KOMUNIKA: Jurnal Dakwah dan Komunikasi, 14 (1), April 2020

Adeni; Silviatul Hasanah (Kontribusi Dakwah Bil Qalam Syaikh Nawawi Al-Bantani...)

\section{Abstrak}

Penelitian bertujuan mengkaji kontribusi Syaikh Nawawi al-Bantani bagi pembentukan nasionalisme pesantren melalui dakwah bil qalam. Metode yang digunakan adalah metode kualitatif, dengan cara mengeksplorasi karya Syaikh Nawawi al-Bantani terutama yang berkaitan dengan jihad dalam konteks kebangsaan yang mencerminkan sikap nasionalisme, kemudian dilihat kontribusinya bagi dunia pesantren. Berdasarkan hasil penelitian menyimpulkan bahwa Syaikh Nawawi al-Bantani berdakwah dengan pendekatan bil qalam, yaitu berupa jihad intelektual. la tidak terlibat langsung dalam aksi perlawanan fisik melawan penjajah, tapi ia menanamkan semangat dan kesadaran akan cinta tanah air ke dalam diri setiap murid-muridnya. Karya Nawawi kemudian diajarkan di dunia pesantren terutama pesantran NU. Ulama seperti KH. Hasyim Asy'ari yang terpengaruh oleh perjuangan Nawawi ini membangun organisasi NU yang tidak hanya tampil sebagai ormas keislaman terbesar, tetapi juga berkontribusi bagi pembentukan awal jati diri bangsa Indonesia. Hal ini terlihat dari keterlibatan $\mathrm{KH}$. Wahid Hasyim dalam sidang BPUPKI-PPKI 1945. Ini menunjukkan bahwa NU memiliki orientasi keislaman yang sama dengan apa yang dipikirkan oleh Syaikh Nawawi. Sikap moderat dan kontekstual Nawawi senantiasa pula mewarnai sepak terjang NU dalam melakukan dakwah keagamaan dan dakwah kebangsaan di Indonesia. Ini juga membuktikan bahwa santri bukan sekadar sebuah entitas keagamaan yang hidup dalam masyarakat Indonesia, tapi pada titik yang sangat menentukan, santri merupakan jati diri bangsa Indonesia itu sendiri.

Kata Kunci:

Dakwah bi al-Qalam, Nawawi al-Bantani, Nasionalisme, Keindonesiaan

\section{PENDAHULUAN}

Perbincangan mengenai hubungan Islam dan nasionalisme tidak bisa dipisahkan dari setiap diskusi kebangsaan di Indonesia (Vandenbosh, 1995). Lebih krusial dari itu adalah bahwa nasionalisme di Indonesia tidak bisa melupakan jasa-jasa para santri. Dunia santri bukan sekadar dunia keagamaan, tetapi merupakan jati diri keindonesiaan dan kebangsaan itu sendiri (Sahmawi, Fanani, \& Nuh, 2018). Hal ini terlihat dari keberadaan pesantren yang tidak hanya merupakan lembaga penyebaran kegamaan saja, tetapi juga sebagai lembaga yang menjadi kekuatan sosial dan kultural (Mastuhu, 1994, p. 60).

Pesantren di Indonesia telah mengambil perannya dalam setiap panggung perjalanan sejarah bangsa Indonesia (Gufron, 2019; Halwati, Alfi, \& Arifin, 2018; Lukens-Bull, 2005). Pesantren membuktikan bahwa ajaran Islam sejalan dengan nasionalisme yang menjadi salah satu nilai Pancasila (Esposito, 2001). Selain itu, tradisi pesantren juga menjadi basis utama bagi pembentukan wajah keislaman di Indonesia (Suprtano, 2019). Namun, di tengah harmoni Islam dan nasionalisme, sebuah gejala mutakhir muncul, yaitu penetrasi arus transnasionalisme Islam yang dikesankan 'bertolak belakang dengan semangat nasionalisme.' Kelompok transansional ini tampil melalui gerakan-gerakan tertentu secara radikal (Roy, 2003). Mereka tidak hanya tampil sebagai kelompok yang mengidentifikasikan diri dengan simbol-simbol keislaman yang formalistik, tetapi juga berusaha merongrong dan mempertanyakan konsep 
nasionalisme dan demokrasi yang selama ini hidup dalam kehidupan masyarakat Indonesia (Azra, 2015, p. 116). Upaya penolakan Pancasila sebagai dasar negara dengan menyebutnya sebagai 'thaghut', adalah hal yang sering mereka suarakan.

Corak Islam transnasional berbeda dengan kultur pesantren yang berkembang di Indonesia. Corak Islam yang dikembangkan dunia pesantren lebih bersifat kultural, sementara Islam transnasional umumnya mengambil jalur dakwah struktural. Hal ini terefleksi dari pergerakan HTI (Hizbut Tahrir Indonesia) yang mencoba secara struktural menegakkan khilafah. Pergerakan struktural melalui jalur politik menjadikan kelompok ini bertentangan dengan negara (state), sehingga kelompok ini pun dibubarkan oleh pemerintah pada 2018 lalu. Pada sisi lain, pesantren justru memperoleh afirmasi untuk mengembangkan tradisi keilmuannya di Indonesia dengan disahkannya UUD Pesantren Nomor 18 Tahun 2019.

Berkaitan dengan fakta ini, muncul pertanyaan bagaimana pesantren bisa eksis sebagai lembaga kultural keislaman dan tetap sejalan dengan semangat nasionalisme di Indonesia. Artikel ini ditulis untuk menunjukkan bahwa tradisi keislaman yang dimiliki pesantren sangatlah unik, dan tentu pembentukan tradisi semacam ini tidak terlepas dari pengaruh tokoh ulama yang memiliki pemikiran keislaman yang terbuka, luwes, ramah, dan fleksibel. Pengembangan corak keislaman yang ramah sangat menentukan bagi kompatibilitas Islam dan negara (Lord, 2016).

Untuk itu, penulis mengambil corak dakwah bil qalam Syaikh Nawawi al-Bantani dalam artikel ini. Syaikh Nawawi adalah seorang Ulama Indonesia berkeliber internasional, namun sangat nasionalis. la seorang yang mumpuni dalam bidang keislaman, meskipun hidup lama sampai meninggal dunia di Mekkah, namun sama sekali tidak mengubah pribadinya sebagai seorang nasionalis sejati yang berjuang demi kepentingan bangsa dan tanah airnya.

Apa yang dipikirkan oleh Syaikh Nawawi terefleksi dengan jelas dari tangan-tangan muridnya yang kembali ke Indonesia. Ulama seperti KH. Hasyim Asy'ari pendiri organisasi keislaman NU (1926) adalah di antara ulama yang tampaknya terinspirasi dengan pemikiran nasionalisme Nawawi al-Bantani yang kemudian mewarnai pergerakan pesantren di Indonesia dalam konteks perlawanan terhadap penjajahan pada masa itu. Sikap organisasi NU yang fleksibel dan tidak memilih tindakan frontal-konfrontatif dalam kehidupan berbangsa dan bernegara sepertinya terilhami oleh pemikiran Nawawi mengenai jihad, di mana berjihad atau melawan pemerintah yang masih menjamin kebebasan penyelenggaraan aktivitas keagamaan bukanlah suatu yang dianjurkan. Sikap demikian tampak sekali menjadi nilai nasionalisme yang distingtif di dunia pesantren. Inilah yang akan dilihat dalam makalah ini.

\section{METODE}

Penelitian ini merupakan studi kualitatif dengan pendekatan dakwah fleksibelitas Islam. Atho' Mudzhar (1998) menyatakan bahwa pendekatan dalam sebuah studi merupakan penggunaan suatu ilmu untuk membaca suatu objek studi. Dalam penelitian ini, keilmuan dakwah dijadikan sebagai pendekatan yang dihubungkan dengan nilai-nilai fleksibelitas Islam melalui konsep rahmatan lil alamin seperti yang telah dipaparkan di atas.

Penggalian data dilakukan dengan cara: pertama, membaca karya-karya Syaikh Nawawi Al-Bantani khususnya yang berkaitan dengan tema-tema kebangsaan dan nasionalisme/cinta tanah air seperti pemahaman Nawawi tentang jihad anti pemberontakan dalam menghadapi kolonial pada masa itu, yakni Kitab al-Futuhat al-Madaniyyah dalam Hamisyh Nasaih alIbad; Kitab Kasyifah al-Saja; Kitab Tanqih al-Qaul al-Hasis; dan Kitab Tawsyaikh ibn Qasim al-Guzzi Qut al-Habib al-Gharib. Kedua, setelah informasi diperolah dari karya-karya tersebut, 
KOMUNIKA: Jurnal Dakwah dan Komunikasi, 14 (1), April 2020

Adeni; Silviatul Hasanah (Kontribusi Dakwah Bil Qalam Syaikh Nawawi Al-Bantani...)

dilakukan refleksi dari sikap nasionalisme kaum pesantren dalam hal ini yang diwakili oleh pesantren NU (Nahdhatul Ulama). Sikap nasionalisme organisasi NU yang didirikan oleh KH. Hasyim Asy'ari dinilai sebagai kekuatan nasionalisme yang sangat terinspirasi oleh sosok Syaikh Nawawi al-Bantani.

\section{HASIL DAN PEMBAHASAN \\ Dakwah Bil Qalam}

Al-Qur'an menjadi basis utama bagi pendekatan dakwah yang satu ini. Surat pertama yang diturunkan "al-Alaq" mengandung ayat "allama bi al-qalam", menjadi indikasi bahwa Allah menginginkan manusia untuk menulis dan berkarya. Ayat ini, menurut Arnez (2009: 5) dapat menjadi pertimbangan bagi Muslim untuk menulis bagi kepentingan kegiatan dakwah, di samping juga menjadi indikasi untuk menjadi orang terdidik. Menulis dalam kegiatan dakwah menjadi penciri dakwah intelektual. Dakwah bi al-qalam (by pen) merupakan bentuk penyampaian kebaikan dan nilai-nilai Islam melalui tulisan (Arnez (2009: 5). Kango (2014: 106) melihat bahwa dakwah bil qalam tampaknya bisa aktif bagi masyarakat Muslim dalam konteks sekarang ini di mana mereka tidak punya cukup waktu untuk datang langsung mengikuti pengajian keagamaan di masjid-masjid. Tentu pendapat ini memiliki kekurangan dalam kaitan dengan perkembangan new media saat ini. Namun hal ini tentu tidak menafikan kontribusi dakwah berupa tulisan dalam mewarnai kegiatan dakwah Islam.

Mengenai urgensi tulisan, Ali Bi Abi Thalib pernah menyatakan, "Tulisan adalah tamannya para ulama." Artinya Ulama dikenal dengan tulisannya. Tulisan menjadi ruh pewarisan keilmuan. Pewarisan keilmuan dari satu generasi ulama ke generasi lain sangat ditentukan oleh tulisan. Apa yang kita kenal dengan kitab Turath atau Kitab Kuning di Indonesia merupakan produk dakwah bil qalam ini. Bagaimana peradaban keilmuan tafsir, hadith, fiqh, tasawwuf, teologi bisa melampaui ruang dan waktu; bisa menyentuh orang yang datang belakangan? Tulisanlah yang membuat Islam punya sejarah keilmuan, tanpa tulisan maka tidak akan ada peradaban keilmuan Islam. Sesuatu yang dipikirkan Ulama pada abad-abad silam dapat kita pelajari dan carikan relevansinya dengan konteks hari ini. Selain berfungsi sebagai wahana keilmuan, tulisan tentu menjadi sarana penting bagi dakwah Islam (Moh. Ali Aziz: 2012). Studi terbaru yang dilakukan Allsra (2019) mengungkapkan bahwa dakwah bil qalam memiliki arti penting bagi perjuangan kelompok Islam di Indonesia baik sebelum dan setelah reformasi. la melihat bahwa para aktivis Islam mulai menggunakan tulisan sebagai media untuk melakukan dakwah ketimbang berkhotbah melalui mimbar-mimbar. Bahkan setelah reformasi da'wah bi al-qalam menjadi lebih terbuka dengan dukungan internet.

\section{Universalisme Ajaran Islam sebagai Ciri Islam yang Nasionalis}

Islam merupakan agama yang ajarannya universal. Adigium yang dapat digunakan untuk menjelaskan ini adalah "Al-Islam shalihun likulli zamanin wamakanin" (Islam relevan untuk semua waktu dan tempat). Islam universal merupakan Islam yang bisa berdamai dengan realitas kebudayaan lain. Nabi Muhammad sendiri, tegas Khalil 'Abd al-Karim (1990, pp. 9-15) dan Wael B. Hallaq (1997, p. 12), tidak pernah memandang kebudayaan Arab pra Islam sebagai bahaya (endangering) yang bisa mengancam tradisi Islam sebagai agama barunya.

Muhammad Quraish Shihab (Shihab, 1995) ketika menjelaskan konsep universalisme Islam menyebutkan istilah al-Waqi'iyyah. Waqi'iyah-nya ajaran Islam tercermin dari prinsipnya yang memberi peluang untuk tidak melaksanakan petunjuk-petunjuknya, apabila 
pelaksanaannya mencapai suatu tingkat gangguan terhadap diri dan atau salah satu aspek dari fitrah manusia. Prinsip yang bersifat universal ini dikenal dengan nama, al-Qawa'id alHimmah, yang memberi semacam hak untuk memveto atau membatalkan rincian petunjuk yang mengakibatkan gangguan tersebut. Prinsip ini antara lain ditarik dari firman-Nya, Q.S. 2: 185 dan Q.S. 5:6).

Selain itu, kandungan al-Quran juga bersifat umum. Ini tentu memberikan ruang kepada akal manusia untuk memikirkan lebih jauh melalui lembaga ijtihad, sesuai dengan konteks situasi tempat dan zaman yang terus berubah (Shabana, 2010, p. 3). Konsekuensi dari keumuman penjelasan Al-Quran itu menjadikan Islam sangat lentur dan fleksibel, selalu dapat diperbarui mengikuti pelbagai perubahan hidup manusia di seluruh dunia. Inilah salah satu sebab mengapa ajaran Islam dan juga peradaban Islam berwatak universal dan cosmopolitan (Madjid, 1995). Selain itu, yang penting dicermati bahwa karakteristik lokal Islam sudah terjadi dan tampak di negeri Arab di mana Islam pertama kali diturunkan. Begitupula keadaannya ketika Islam dihadirkan dalam konteks masyarakat lain yang berbeda (Wolters, 1998, II. 1-18).

Konsep universalitas Islam ini menemukan jati dirinya secara manifestatif dalam konteks hubungan Islam dan nasionalisme. Dalam konteks negara-bangsa (nation-state), karakter Islam yang mau berdamai dengan lokalitas cenderung lebih akomodatif terhadap nasionalisme (Woodward, 2011, p. 67). Dan ini tentu merupakan salah satu ciri yang melekat pada Islam kultural. la senantiasa dinamis dalam menghadapi segala varian realitas yang muncul.

Penerimaan terhadap nasionalisme pada gilirannya juga mengimplikasikan penerimaan terhadap sistem demokrasi. Demokrasi Indonesia bukan semata-mata faksimili dari gagasan aslinya dari Barat, tapi merupakan demokrasi formal yang tidak tegak kecuali jika kekuasaan negara dibatasi dengan organisasi-organisasi masyarakat madani yang kuat. Pada saat yang sama pula, organisasi-organisasi masyarakat madani dan budaya demokrasi tidak bisa tumbuh baik kecuali jika mereka dilindungi oleh negara yang menjunjung tinggi rule of law (Hefner, 2000). Artinya sistem yang berkembang di Indonesia saat ini tidak bisa menafikan peran organisasi masyarakat madani. Dan wujud sebuah kekuatan yang sempurna adalah ketika organisasi masyarakat madani bersinergi dengan negara dalam mencapai tujuan bersama.

Dalam konteks ini, dapat dikatakan bahwa di Indonesia, keberadaan nasionalisme bukan semata-mata produk Barat, yang diimpor ke Indonesia, tetapi nasionalisme Indonesia adalah sebuah entitas yang lahir dari penghayatan secara mendalam masyarakat atas keperihatinan yang dihadapi secara bersama pada masa kolonial dahulu. Karena itu, keterlibatan ormas keislaman dalam perumusan Pancasila pada 22 Juli 1945 menjadi sentral bagi titik temu agama (Islam) dan negara. Sidang PPKI yang menghasilkan Pancasila itu sejatinya bagi kelompok Islam bukan sekadar mencari titik temu, tapi itu dengan sendirinya menunjukkan sebuah ciri dan sikap pandangan keislaman yang sangat akomodatif dan kontekstual, khususnya setelah ungkapan "Ketuhanan, dengan kewajiban menjalankan Syariat Islam bagi pemelukpemeluknya" dihilangkan.

Salah satu ormas keislaman kultural yang kental dengan nasionalisme adalah dan NU. Nasionalisme organisasi ini tampak di antaranya dalam afirmasinya atas pembentukan negara-bangsa (nation-state) Indonesia, bukan negara Islam. Ini terjadi dengan keterlibatan KH. Wahid Hasyim pada Sidang BPUPKI-PPKI 1945. Selain itu, penerimaan atas Pancasila pada Munas Alim Ulama di Situbondo (1983), dan Maklumat Penyelamatan NKRI dan Pancasila dari fundamentalisme agama dan pasar pada Harlah ke-85 NU (2011), bisa juga menjadi bukti keberpihakan NU kepada nasionalisme bangsa (Muhammad, 2015). 


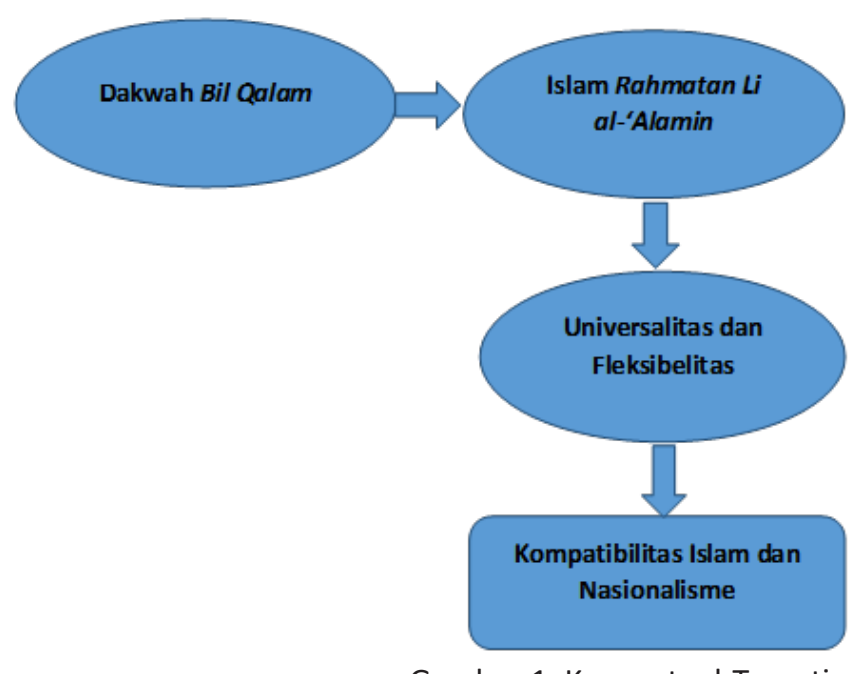

\section{Syaikh Nawawi al-Bantani: Figur Ulama Nasionalis}

Syaikh Nawawi merupakan seorang ulama yang nasionalis. Setidaknya nasionalisme dalam arti sederhana, 'cinta tanah air.' Sikap nasionalismenya tampak dari upayanya mengobarkan perlawanan terhadap kolonial di tengah-tengah umat sepulangnya dari Mekkah ketika itu. Namun, karena mendapat tekanan dan pengawasan dari pemerintah kolonial, ia kembali ke Mekkah dan menetap di sana sampai akhir hayatnya. Di kota suci inilah ia bebas mengembangkan diri dan mendalami ilmu agama, sehingga ia menjadi seorang Ulama yang dikenal. Tinggal di Mekkah, sama sekali tidak memadamkan semangat nasionalismenya, karena di kota suci ini ia mendidik murid-muridnya dengan semangat cinta tanah air yang tinggi.

Selain itu, karya-karya beliau pun lebih merupakan respons atas fenomena sosialkeagamaan di tanah air kala itu. Hal ini tampak ketika ia dimintai komentar oleh Sayyid Usman terhadap Kitab al-Nasihah 'ala al-Niqah. Buku al-Nasihah 'ala al-Niqah merupakan buku yang memuat sikap penentangan Sayyid Usman terhadap pengalaman tarekat, khususnya tarekat Naqsyabandiyah. Dukungan dari ulama yang mumpuni secara keilmuan dan disegani di Mekkah, seperti Syaikh Nawawi, sangat diperlukan oleh Sayyid Usman. Dalam Nawawi komentarnya, Nawawi menyatakan bahwa tarekat yang sejalan dengan syara dan sunnah Nabi, maka dapat diterima, sementara tarekat yang tidak sejalan dengan jalan syariat harus ditolak dan tidak dapat diterima seperti yang banyak terjadi dalam diri anak-anak murid Syekh Ismail Minangkabau (Karel, 1984, p. 184). Sikap Nawawi ini menggambarkan sebuah kepedulian terhadap kondisi tanah air waktu itu di mana sangat berkembang tarekat yang melenceng dari sunnah dan syariat.

Selain itu, Nawawi juga menulis buku berjudul Qami' al-Tugyan. Buku ini merupakan syarah atau ulasan terhadap Manzumah Syu'ab al-Iman yang ditulis oleh Zainuddin alMaribari. Buku Nawawi yang satu ini juga ditulis untuk memenuhi kebutuhan orang-orang Indonesia (Nawawi, n.d.-a, p. 2). Hal ini terlihat jelas dalam pengantar bukunya, ia menulis "لأبناءجني" (buku ini ditulis untuk anak-anak bangsaku). Hal yang sama juga dinyatakan oleh Nawawi (n.d.-b, p. 2) dalam pengantar bukunya yang lain, yaitu kitab Kasyifah al-Saja'. yang merupakan sebuah syarah atau ulasan terhadap Safinah al-Naja yang ditulis oleh Salim ibn Sumair al-Hadrami. Sampai saat ini Safinah al-Naja masih menjadi rujukan keagamaan dalam 
bidang fiqh oleh umat Islam di Indonesia. Tampaknya usaha Nawawi memberikan ulasan atas kitab tersebut menunjukkan sebuah kepedulian yang luar biasa dari Nawawi terhadap fiqh yang sejalan untuk konteks masyarakat Indonesia.

Keperihatinan Nawawi terhadap kondisi Indonesia tidak hanya sebatas itu. Nawawi adalah Ulama yang tidak jarang mencari dan membangun relevansi sebuah karya sejaumana digunakan oleh banyak orang. la menghasilkan karya yang kontekstual dengan kebutuhan masyarakat. Upaya ini terlihat dari karyanya yang berjudul Tanqih al-Qaul al-Hatsits, sebuah syarah atau ulasan terhadap kitab Lubab al-Hadis yang ditulis Imam Suyuti. Kitab Imam Suyuti ini sangat banyak digunakan di Jawa (Nusantara) ketika itu. Nawawi (n.d.-c, p. 2) melihat karya Suyuti ini telah mengalami banyak tashrif (kekeliruan) dan tashrif (kesalahan), sementara kitab ini digunakan orang-orang Jawa ( $a h l$ Jawa) sebagai salah satu pedoman keagamaan. Kekeliruan dan kesalahan yang dimaksud memang tidak dijelaskan secara detail oleh Nawawi, tapi ia menyatakan bahwa tidak ditemukan naskah yang benar (nuskhat shahihah) terkait kitab yang telah beredar di Jawa itu.

Ini semua merupakan bukti bahwa Nawawi adalah seorang Ulama yan nasionalis. la sangat perhatian dengan nasib tanah air pada waktu itu, yang hidup dalam hegemoni penjajah kolonial di satu sisi, dan tenggelam dalam tradisi kepercayaan dan keberagamaan yang tidak realistis dan tidak sesuai dengan ajaran Islam di sisi lain. Nawawi tampaknya paham betul bahwa untuk mengubah masyarakat harus berangkat dari apa yang mereka yakini. Karenanya, Nawawi membuat karya-karya yang mengajarkan keyakinan Islam yang benar sesuai dengan al-Qur'an dan al-Sunnah yang dapat mencerdaskan umat, sehingga bisa melakukan perlawanan terhadap penjajah yang saat itu lebih maju dari segi pendidikan.

Upaya Nawawi sebagaimana dipaparkan di atas sejalan dengan watak dakwah Islam yang kontekstual. Nawawi tidak menulis buku-buku yang berisi dorongan untuk berbuat makar atau bernuansa politik. Sikap seperti ini sejalan dengan prinsip al-Waqi'yah yang menjadi pertimbangan dalam melakukan dakwah Islam dengan selalu melihat kebutuhan dan konteks masyarakat yang didakwahi. Tampaknya Nawawi menjalankan prinsip ini dalam dakwahnya.

\section{Jihad Intelektual (bil Qalam) Syaikh Nawawi al-Bantani dan Kontri- businya bagi Nasionalisme Kaum Pesantren}

Sejatinya antara jihad fisik dan jihad intelektual tertanam kuat dalam diri seorang Nawawi al-Bantani, tetapi ia lebih memilih jihad intelektual. Pilihan itu, bukan karena ia benci untuk berperang, tapi lebih merupakan pendekatan dakwah yang sengaja ia pilih. Buktinya ia memang tidak terjun ke medan perang secara praktis dengan mengangkat senjata, tapi ia berperang melawan ketidakadilan dan penindasan dengan pena (tulisan). Melalui kerja intelektual ia menanamkan semangat perlawanan terhadap kolonial ke dalam diri muridmuridnya. Hurgronje, dalam pembicaraan pribadinya dengan Nawawi, menuliskan bahwa Nawawi tidak pernah berkeinginan untuk mengambil peran dalam bentuk politik seperti Ayah dan saudaranya Ahmad, sebagai pegawai pemerintah kafir kala itu. Nawawi terlihat bijak sekali dalam memahami bahwa setiap orang mengambil peran dan tugasnya sesuai dengan bidang masing-masing (Ibrahim, 1989, p. 153).Semen tara itu, Nawawi al-Bantani lebih memilih jihad intelektual. Menurut Hurgronje keistemewaan dan kelebihan Syaikh Nawawi yang sangat berharga terletak pada penanya. la seorang yang alim dan produktif (Karel, 1984). Syaikh Nawawi lebih intensif dan aktive melakukan jihad intelektual ketimbang jihad fisik. Cara ini merupakan salah satu ciri langkah dakwah kultural yang ia lakukan. 
Berbeda dengan ulama lainnya dari Nusantara, Nawawi menulis buku karyanya dalam bahasa Arab. Melalui cara ini Nawawi ingin menegaskan bahwa pemahaman Islam harus dilandasi dengan kemampaun berbahasa Arab yang baik dan mumpuni, namun bukan bearti melakukan Arabisasi dengan memaksakan produk budaya Arab untuk masyarakat lokal Indonesia. Karenanya, meski karya Nawawi seluruhnya berbahasa Arab, tapi konten dan kandungannya sangat kontekstual dengan kebutuhan lokal masyarakat Nusantara ketika itu. Karya Nawawi umumnya adalah ulasan atau penjelasan terhadap kitab-kitab besar agar mudah dipahami orang awam (Bruinessen, 1991, p. 143). Melalui karya-karyanya, Nawawi dapat dikatakan sebagai ulama yang sangat berjasa dalam membumikan kitab-kitab klasik berbahasa Arab di Indonesia khususnya di dunia pesantren. Seluruh karya Syaikh Nawawi diperkirakan mencampai lebih dari seratus buah kitab, atau sebanyak 115 kitab (Rafiudin, n.d., p. 8). Karyanya yang banyak membuatnya sangat popular, bahkan Martin Van Brunessen (Bruinessen, 1991) menempatkan popularitas Nawawi sejajar dengan Ulama asal Mesir, Ibrahim al-Bajuri (w. 1277 H/1861 M).

Dakwah yang dilakukan oleh Nawawi ini cukup signifikan pengaruhnya bagi perkembangan Islam di tanah air. Selain kitab-kitabnya banyak digunakan di dunia pesantren, ia juga melahirkan ulama-ulama yang nasionalis. Murid-muridnya banyak yang terlibat langsung dengan perjuangan nasionalisme praktis di tanah air. Mereka adalah $\mathrm{KH}$. Arsyad ibn Alwan, KH. Mas Muhammad Arsyad Thowil ibn Imam As'ad, KH. Marzuki, dan KH. Hasyim Asy'ary (Bruinessen, 1991). Tokoh-tokoh agama, murid Nawawi ini, adalah di antara mereka yang aktive melakukan perlawanan dan konfrontasi terhadap pemerintah kolonial pada masa itu. Mereka terlibat dalam aksi-aksi praktis perlawanan melawan penjajah. Pengaruh Nawawi sangat kuat dalam diri mereka.

Dakwah Nawawi sangat dinamis dan kontekstual serta selalu bercorak kultural. Hal ini terlihat ketika beliau menolak tindakan jihad mengangkat senjata di zamannya ketika jihad hanya mendatangkan bahaya lebih besar bagi diri sendiri dan orang lain, karena hal itu menurutnya sama saja dengan tindakan bunuh diri. Bagi Nawawi (n.d.-d, p. 225), jihad wajib dilakukan apabila ada kesiapan berperang dengan kemampuan untuk mengangkat senjata (al-thaqah 'ala al-qital). Ketesediaan senjata dan seluruh perlengkapan perang harus menjadi syarat utama kewajiban jihad dalam pengertian fisik. Jika penduduk di suatu wilayah dikepung oleh musuh dan mereka (penduduk) tidak memiliki kesiapan dan kemampuan untuk melawan maka yang diutamakan adalah perdamaian (al-istis/am), bukan memaksakan terjadinya peperangan. Dalam batas tertentu suatu penduduk boleh bersikap kooperatif untuk taat pada aturan yang diterapkan oleh penguasa selama tidak melanggar prinsip-prinsip pokok dalam syariat Islam (Nawawi, n.d.-d). Tampaknya Nawawi paham betul pemaknaan Ulil Amri dalam konteks Nusantara.

Konsep Nawawi ini dapat diterima, karena sejatinya jihad bertujuan untuk menegakkan agama (li-iqamati al-din). Karenanya, selama terdapat kemudahan dan tidak ada larangan dalam mengamalkan ajaran agama (Islam), maka aturan pemerintah dalam bentuk apapun wajib diikuti meskipun pemerintah yang berkuasa adalah orang kafir (non-Muslim). Umat Islam tidak harus melakukan jihad mengangkat senjata selama ajaran agama masih bebas dilaksanakan tanpa larangan di bawah suatu pemerintah yang berkuasa. Hurgronje menggambarkan sikap Nawawi ini dalam surat-menyuratnya kala itu. Menurutnya, Syaikh Nawawi melihat bahwa orang-orang yang terlibat dan tewas dalam pertempuran baru-baru ini di Banten sebagai para oknum yang membinaskan diri dan mereka tidak bisa dianggap sebagai syuhada (Gobee, 1995, p. 2141). Kendati demikian, sikap Nawawi tentang istislam di 
atas tidaklah berlaku mutlak dan general. Nawawi melihat bahwa pemerintah yang berbuat sewenang-wenang terhadap suatu penduduk harus dilawan ddengan cara apapun. Hal ini dinyatakan Nawawi dalam al-Futuhat al-Madaniyah. Menurutnya, aturan pemerintah yang wajib diikuti hanyalah ketika aturan itu tidak bertentangan syariat Islam, yaitu dalam halhal yang bernuasa mubah dan mu'amalah. Namun dalam hal kemaksiatan, atau mereka melakukan pemerasan terhadap kamu, maka hadapilah mereka dengan cara-cara kamu (Nawawi, n.d.-a).

Sepintas memang tampak inkonsistensi dalam sikap Nawawi tentang jihad dan istislam, tetapi itu justru menunjukkan watak dinamis pemahaman keislaman Nawawi al-Bantani. la tampaknya melakukan pendekatan kontekstual dan kondisional. Jika dua pendapat Nawawi tersebut digabungkan maka akan menghasilkan sebuah rumusan bahwa boleh saja berjihad jika memungkinkan atau memilih damai jika bahaya yang didatangkan lebih besar.

Tabel 1: Sikap Nawawi al-Bantani terhadap Jihad

\begin{tabular}{|l|l|l|}
\hline No & \multicolumn{1}{|c|}{ Pilihan Jihad } & \multicolumn{1}{c|}{ Tindakan yang Dianjurkan } \\
\hline 1 & $\begin{array}{l}\text { al-Istislam (berdamai) dan } \\
\text { bersikap kooperatif ketika satu } \\
\text { wilayah dikuasai sepenuhn- } \\
\text { ya oleh musuh, sedangkan } \\
\text { penduduknya tidak mampu } \\
\text { melakukan perlawanan. }\end{array}$ & $\begin{array}{l}\text { Jihad dalam arti perang bukan Jalan } \\
\text { yang dianjurkan karena mudharat yang } \\
\text { ditimbulkan jauh lebih besar. }\end{array}$ \\
\hline 2 & $\begin{array}{l}\text { al-Thaqah al-Qital (mampu } \\
\text { berperang) dalam konteks pe- } \\
\text { merintah bersikap tirani atau } \\
\text { bertindak sewenang-wenang. }\end{array}$ & Wajib berjihad (berperang), dilakukan \\
perlawanan dalam bentuk apapun
\end{tabular}

Sikap dakwah dinamis Syaikh Nawawi ini pula tampaknya yang secara spesifik mengispirasi model dakwah yang dijalankan oleh organisasi terbesar Islam di Indonesia, yaitu NU (Nadhlatul Ulama), yang didirikan oleh KH. Hasyim Asy'ari pada 1926. Hasyim Asya'ri berangkat untuk menimba ilmu dan menunaikan ibada haji ke Mekkah pada 1892. Ia akhirnya kembali ke tanah air karena istri dan anak yang dilahirkan meninggal dunia. la kemudian kembali ke Mekkah untuk menimba ilmu pada 1893 dan menetap di Kota Suci ini selama enam tahun. Ia mendalami ilmu agama di Mekkah dari Nawawi al-Bantani. la bahkan memiliki kesan yang mendalam dengan Syaikh Nawawi (Dahlan, 1978, p. 7). Pada 1899 ia kembali ke tanah air dan mendirikan pesantren di Tebuireng, Jombang. Pada perjalanan selanjutnya, dia dikenal sebagai deklarator pendiri organisasi Nahdhatul Ulama (NU).

NU merupakan salah satu basis kekuatana keislaman terbesar di Indonesia. Watak NU yang moderat (wasathiyyah) membuatnya bisa mencapai seluruh lapisan masyarakat, dari perkotaan hingga pedesaan. Watak moderasinya pula yang menghantarkan NU menjadi salah satu Ormas keislaman yang turut terlibat dalam perumusan Pancasila yang menjadi dasar negara Indonesia. Hal terpenting, bukan hanya sekadar terlibat, tapi penerimaan atas Pancasila. NU yang tampil sebagai ormas yang menunjunjung tinggi semangat nasionalisme sungguh tidak bisa dinafikan terinspirasi dari model dakwah kultural yang moderat dan dinamis Syaikh Nawawi al-Bantani, guru KH. Hasyim Asy'ari. Syaikh Nawawi boleh dikatakan sangat berjasa bagi pembentukan karakter keislaman NU dan kultur pesantren yang selama ini menjadi ciri khas dan identitas besar Islam Indonesia.

Sikap Nawawi yang kooperatif atau mau berdamai dengan pemerintah kolonial ketika bahaya yang muncul jauh lebih besar, tampaknya teraktualisasi jelas dalam sikap penerimaan 
NU terhadap Pancasila. NU akhirnya menerima Pancasila menurut versi Soekarno dan Mohammad Hatta setelah sebelumnya tujuh kata keramat dihilangkan. Tampaknya, yang menjadi pertimbangan NU adalah agar Indonesia dan umat Islam khususnya, terbebas dari bahaya setelah kemerdekaan diproklamasikan. Bahaya itu bisa dalam bentuk bahaya internal seperti terjadinya persitegangan antara Muslim dan non-Muslim yang bisa merusak keadaan internal kebangsaan. Kendatipun tidak dapat menjadikan Indonesia sebagai negara Islam (Islamic state), tapi penerimaan terhadap sila pertama "Ketuhanan yang Maha Esa, cukup mengindikasikan adanya jaminan keagamaan bagi umat Islam. Sikap ini persis seperti sikap yang diambil oleh Nawawi al-Bantani dalam masalah jihad dalam merespons fenomena pemberontakan terhadap penjajah kolonial di daerah Banten kala itu. la memilih berfatwa agar berdamai dengan pemerintah kolonial, asalkan diberi kebebasan dalam menjalankan aktivitas keberagamaan sehari-hari.

Kendati demikian, seperti halnya sikap Syaikh Nawawi al-Bantani, dinamika lain juga tampak dalam tubuh NU. Selain bersikap pro terhadap bentuk negara nation-state (tidak Islam), NU juga menampilkan sikap nasionalisme dengan perlawanan terhadap penjajah yang jelas-jelas sangat sekuler dan tidak Islam. Ini tampak dalam salah satu fatwa KH. Hasyim Asy'ari tentang "Resolusi Jihad," berisi:

a. Kemerdekaan Indonesia yang telah diproklamirkan pada tanggal 17 Agustus 1945 harus dipertahankan.

b. Pemerintah RI sebagai satu-satunya pemerintahan yang sah harus dipertahankan dengan harta maupun jiwa.

c. Musuh-musuh Indonesia khususnya orang-orang Belanda yang kembali ke Indonesia dengan menumpang pasukan sekutu (Inggris) sangat mungkin ingin menjajah kembali bangsa Indonesia setelah Jepang ditaklukan.

d. Umat muslim khususnya warga NU harus siap bertempur melawan Belanda dan Sekutu mereka yang berusaha untuk menguasai kembali Indonesia.

e. Kewajiban Jihad merupakan keharusan bagi setiap muslim yang tinggal dalam radius 94 kilometer (sama jaraknya, masafah, dimana menjamak shalat boleh ditunaikan oleh santri muslim). Mereka yang berada dalam radius itu mempunyai tanggung jawab untuk mendukung saudara-saudara muslim mereka yang tengah berjuang dalam radius tersebut (Mas'ud, 2006, pp. 265-266).

Kiai Hasyim Asy'ari memiliki nasionalisme yang tinggi. Tindak kekerasan terhadapnya tidak menghentikan langkahnya dalam perjuangan mempertahankan martabat bangsa Indonesia. Semangat nasionalisme dimanifestasikan melalui perjuangan melalui diplomasi. Keberadaan resolusi jihad yang dipicu adalah bukti kepedulian KH Hasyim terhadap martabat bangsa Indonesia. Dengan demikian, pesantren hadir sebagai pelaku sejarah dari serangkaian kehidupan berbangsa. Kehadiran film "Sang Kiai" semakin memperkuat keterlibatan pesantren dalam perjuangan Indonesia (Winet, 2009).

Paparan di atas menunjukkan bahwa secara tidak langsung Syaikh Nawawi al-Bantani memang tidak terlibat dalam gerakan nasionalisme di tanah air, tapi ia menginspirasi secara cukup signifikan pergerakan murid-muridnya. la memilih jihad intelektual, yaitu jalan pendidikan. la ambil jalan pendidikan sebagai upaya membangun karakter diri, jiwa dan semangat keislaman dan keindonesiaan yang kuat ke dalam diri murid-muridnya. Dan dari tangan para muridnyalah api nasionalisme menemukan bentuknya berupa perlawanan fisik melawan penjajah. 


\section{Jihad Kaum Pesantren untuk Nasionalisme}

Pesantren tidak bisa dipisahkan dari jati diri Indonesia. Ronika, Syamsuddin, \& Kuswanjono (2019) menyatakan, "nationalism was influenced by religiosity value." Keberadaan lembaga ini dikenal di Nusantara pada abad 13-17 M (Mastuhu, 1994). Sementara di pulau Jawa, lembaga ini didirikan untuk pertama kalinya di era Walisongo (Kafrawi, 1978, p. 78). Secara historis, pesantren sebagai lembaga pendidikan dan pusat penyebaran Islam lahir dan berkembang sejak awal kedatangan Islam di Indonesia (Alfi, 2020). Hal yang unik adalah bahwa pesantren bukan semata-mata identik dengan makna Islam atau keislaman, tetapi juga mengandung makna autentisitas (asli) Indonesia (Madjid, 1997, p. 3). Ini tampaknya terjadi karena pesantren lahir dari masyarakat dan bergumul dengan persoalan-persoalan yang dihadapi oleh mereka. Pesantren terlibat langsung dengan dinamika perjalanan dan perjuangan kehidupan Indonesia.

Berkaitan dengan jihad nasionalisme, terdapat beberapa hal yang melekat dengan pesantren, yaitu:

Pertama, pesantren sebagai salah satu elemen penting dalam dinamika perjuangan bangsa Indonesia. Secara historis, seperti disampaikan A. Muhammad (Muhammad, 2015), pesantren telah telat terlibat dalam berbagai peristiwa penting di Indonesia, baik sejarah sosial, budaya, ekonomi dan politik Indonesia. Selama masa penjajahan, pesantren sebagai tempat di mana kiai dan santri hidup, mengalami posisi yang begitu berat. Tekanan demi tekanan dirasakan oleh kiai dan santri dalam menyebarkan ajaran agama serta memperjuangkan hak mereka untuk hidup di tempat yang aman dan damai. Fakta sejarah menjelaskan bahwa pesantren adalah musuh penjajah. Dengan demikian, tidak mengherankan jika perjuangan mengusir penjajah berangkat dari masyarakat umum dan pesantren dengan dasar memberikan pendidikan kepada kaum tertindas (Hasan, 2014: 3). Keduanya bersatu untuk mengusir penjajah dari tanah air dengan segala upaya dan kekuatan.

Kedua, pesantren adalah lembaga pendidikan yang berbasis pada masyarakat. Pesantren adalah lembaga yang memiliki basis tradisi dan kultur yang mengakar dengan kehidupan masyarakat setempat. Karena ia berdiri di atas tradisi dan kultur masyarakat setempat, pesantren jarang sekali didapati menjadi wahana bagi tindakan-tindakan destruktif bagi tatanan masyarakat yang telah mapan. Jika dilihat dari fakta historis pada masa penjajahan tampak jelas bahwa lembaga pesantren menjadi tempat bersemainya perlawanan melawan penjajah. Kraemer seperti dikutip oleh Zamakhsyari Dhofier (2011, p. 21) melihat bahwa meskipun Belanda memberlakukan pembatasan, faktanya Islam melalui pesantren menjadi daya tarik utama sebagai tempat perjuangan melawan penjajah Belanda selama tiga setengah abad. Pada akhirnya ajaran pendidikan dari pesantren memperoleh tempat khusus di hati masyarakat sementara pada saat yang sama berfungsi sebagai pusat penyebaran Islam di masa itu.

Pesantren di Indonesia yang umumnya didominasi oleh pesantren tradisional merupakan lembaga dakwah dan pendidikan yang berjalan dengan semangat kultural. Pesantren, tegas Azra, Afriyanti, \& Hefner (2020), tidak bergantung dengan pemerintah (state). la berdiri dengan kaki sendiri atas dasar semangat sosial yang tinggi dari pendirinya. la umumnya dibangun di pedesaan yang ditujukan untuk memenuhi kebutuhan pendidikan masyarakat di desa.

Ketiga, sebagai implikasi dari keterlibatan pesantren dengan perjuangan Indonesia adalah menguatnya semangat toleransi dalam tubuh pesantren. Kedekatan dengan masyarakat setempat menjadikan pesantren tampil lebih fleksibel dan menyesuaikan 
diri dengan kebiasaan yang berlaku di masyarakat. Di sisi lain toleransi di dunia pesantren didukung dengan pengajaran kitab-kitab ulama klasik yang penuh dengan khilafiyah antara satu ulama dengan yang lain. Para santri pesantren sudah sangat terbiasa dengan perbedaan yang terjadi antara para ulama. Perbedaan para ulama ini menghasilkan sikap santri yang terbuka dan selalu bijaksana dalam menilai suatu perbedaan pendapat. Tentu pada gilirannya sikap keterbukaan kaum pesantren ini membuat pesantren terbuka pula menerima Indonesia sebagai negara yang tidak harus berlandaskan hukum Islam. Pernyataan ini sejalan dengan pandangan Hefner (Hefner, 2000) yang melihat bahwa pendidikan modern dan konstitusionalisme di negara demokrasi Pancasila bukanlah semata-mata merupakan proses sekularisasi yang berorientasi pada Barat, tetapi hanyalah isntrumen politik yang sepenuhnya sejalan (compatible) dengan Islam.

Pesantren memiliki peran dalam mewujudkan nilai-nilai toleransi di Indonesia (Abdurrachim, 2016). Ini telah dirumuskan dalam tiga pilar, yaitu nilai-nilai dasar pesantren, perspektif multikulturalisme, dan etika sosial masyarakat (Alfi, 2020; Nisa \& Mahbib, 2013). Pertama, nilai-nilai dasar pesantren adalah tawasuth (sedang), tawazun (seimbang), dan tasamuh (toleran). Kedua, perspektif multikulturalisme adalah sikap seseorang yang dapat memahami dan menerima perbedaan dan keragaman di sekitarnya yang meliputi tiga hal, pengakuan (pengakuan dan penghargaan), representasi (rentan terhadap suatu fenomena), dan redistribusi (mampu mengatasi perbedaan dengan baik, tidak reaktif, dan tidak mudah terkejut). Ketiga, etika sosial diwujudkan dalam norma-norma yang berlaku di masyarakat, seperti berbuat baik kepada siapa pun, menciptakan suasana yang kondusif, dan bersikap adil untuk memberikan hak secara proporsional atas dasar cinta sesama manusia (Mustafid, 2012). Nilai-nilai tersebut terimplementasi dengan baik di dunia pesantren.

Berkat upaya para pesantren (kiai) dan santri (murid), pesantren mampu menentukan karakter atau wajah keislaman masyarakat Indonesia yang lentur, toleran, dan fleksibel. Pernyataan ini dijelaskan oleh Soebardi dan John yang melihat bahwa pesantren mampu mempengaruhi karakter Islam dan memainkan peran paling penting untuk penyebaran Islam ke pedesaan. Dari lembaga-lembaga pesantren ini, sejumlah naskah pengajaran Islam dikumpulkan. Untuk dapat memahami sejarah Islam di Indonesia, itu harus melibatkan pesantren, karena lembaga ini menjadi panah penyebaran Islam di beberapa daerah (Dhofier, 2011). Kendati demikian belakangan ini tidak jarang lembaga keagamaan seperti ini dicurigai sebagai sarang radikalisme dan terorisme. Hal ini terjadi karena pengaruh pesantren dengan ideologi radikalisme yang menamakan diri mereka sebagai salafisme, khususnya salaf-jihadis (Wahid, 2014).

Keempat, pesantren menjadi wahana penguatan pendidikan karakter. Pendidikan di lingkungan pondok pesantren berkontribusi pada pembangunan karakter yang menjadi sumber nilai bagi penguatan nasionalisme. Pendidikan di sekolah asrama seperti pesantren memberikan santri kebijaksanaan dalam beragama agar selaras dengan semangat nasionalisme Indonesia. Peran pondok pesantren sesuai dengan tujuan agama, selaras dengan tujuan negara, juga sejalan dengan tantangan masa depan. Di pesantren anak-anak dapat belajar secara panjang dan intensif dengan contoh nyata. Pesantren membekali anak-anak dengan pengetahuan agama yang tinggi, keterampilan yang baik, dan karakter yang mulia (ACDP, 2017). Pesantren mengajarkan hidup saling tolong menolong dan penuh kebersamaan. Di suatu pesantren para santri berdatangan dari berbagai daerah di Indonesia dengan latar belakang yang berbeda. Hidup di pesantren mendidik mereka untuk melepaskan segala bentuk kebesaran yang melekat dengan keluarga mereka. Di pesantren si kaya dan si miskin hidup 
dalam satu asrama yang sama, tanpa pembedaan kelas. Mereka hidup mandiri dan melebur dengan kebiasaan santri-santri lain di pesantren. Ini menjadi nilai yang sangat berharga yang mampu memupuk semangat kebersamaan dan perasan senasib sepenanggungan.

Selain itu, kehidupan di pesantren menawarkan konsep kesederhanaan kepada santri agar memiliki sikap zuhud, seperti yang dicontohkan oleh Nabi Muhammad SAW, dan tidak serakah dalam menikmati kehidupan duniawi. Nilai kesederhanaan dianggap penting dalam budaya kehidupan pesantren sebagai bentuk upaya pelatihan diri untuk tidak tertidur dengan kehidupan dunia secara berlebihan. Kesederhanaan ini adalah salah satu ciri pesantren yang ditanamkan pada santri (Shobirin, 2018). Sikap ini pada giliran yang lain sangat berguna bagi pembentukan jiwa santri yang tidak serakah dalam kehidupan berbangsa dan bernegara. Nilai seperti ini sangat diperlukan dalam konteks maraknya kasus korupsi yang terjadi di Indonesia saat ini.

Kelima, keterlibatan santri di ruang publik. Bukti nyata lainnya berdasarkan kajian Hanan (n.d.) kecintaan para santri kepada bangsa Indonesia adalah keikutsertaan mereka dalam acara seremonial perayaan hari ulang tahun kemerdekaan Indonesia. Pada setiap tanggal 17 Agustus, ratusan santri dari berbagai pesantren ikut merayakannya. Mereka mengenakan pakaian sehari-hari normal mereka, yaitu, sarung dengan kemeja dan topi peci hitam untuk anak laki-laki dan rok panjang atau batik dengan atasan longgar dan jilbab untuk anak perempuan. Di antara pesantren yang terlibat ikut serta adalah pesantren Sidogiri di Pasuruan, An-Nur di Malang, Darul Huda di Ponorogo, Tremas di Pacitan, Bumi Sholawat di Sidoarjo, Salafiyah di Situbondo, Khas Kempek di Cirebon, Dalwa di Pasuruan, Darussalam di Keputih Surabaya.

Keikusertaan para santri ini tidak bisa dinilai remeh sebagai tindakan seremonialformalistik belaka. Sebagaimana diketahui bahwa akhir-akhir ini keberanian berekspresi di ruang publik mampu menunjukkan eksistensi suatu identitas. Belakangan ini Indonesia dihadapkan dengan gelombang Islam yang secara radikal dan ekstrem menampilkan watak Islam yang tidak ramah di ruang publik, seperti pengrusakan fasilitas umum, pengeboman/ terorisme di tempat ibadah, termasuk perlawanan secara terbuka terhadap ideologi Pancasila. Ekspresi semacam ini perlu dilawan dengan gerakan yang seimbang pula. Gerakan keikutsertaan para santri dalam perayaan kemederkaan pada 17 Agustus dengan kekhasan tradisi dan kebudayaan pesantren dapat dinilai sebagai bentuk penyeimbangan terhadap eksistensi kelompok Islam radikal itu (Zuhdi, 2018). Bahkan pada giliran yang lain, tampilnya para santri yang berhaluan moderat di ruang publik dalam menyuarakan nasionalisme mampu mengembalikan citra Islam yang tidak jarang dinilai beringas, ekstrem, dan tidak sejalan dengan negara demokrasi.

Tabel 2. Jihad Pesantren untuk Nasionalisme

\begin{tabular}{|l|l|l|}
\hline No & \multicolumn{1}{|c|}{ Nasionalisme Pesantren } & \multicolumn{1}{|c|}{ Basis Nasionalisme } \\
\hline 1 & $\begin{array}{l}\text { Pesantren sebagai salah satu elemen } \\
\text { penting dalam dinamika perjuangan } \\
\text { bangsa Indonesia }\end{array}$ & Basis historis nasionalisme pesantren \\
\hline 2 & $\begin{array}{l}\text { Pesantren adalah lembaga pendi- } \\
\text { dikan dan dakwah yang berbasis } \\
\text { pada masyarakat }\end{array}$ & Basis sosial nasionalisme pesantren \\
\hline 3 & Pesantren sebagai rumah toleransi & Nilai/prinsip nasionalisme pesantren \\
\hline
\end{tabular}




\begin{tabular}{|l|l|l|}
\hline 4 & $\begin{array}{l}\text { Pesantren menjadi wahana pengua- } \\
\text { tan karakter (Akhlaq Karimah) }\end{array}$ & Nilai/prinsip nasionalisme pesantren \\
\hline 5 & Keterlibatan santri di ruang publik. & $\begin{array}{l}\text { Wujud ruang gerak nasionalisme pe- } \\
\text { santren. }\end{array}$ \\
\hline
\end{tabular}

\section{SIMPULAN}

Dari paparan di atas dapat disimpulkan bahwa nasionalisme berbasis Islam yang terbangun dalam kehidupan santri di Indonesia sangat terilhami oleh figur kebangsaan Syaikh Nawawi al-Bantani. Nawawi menguatkan nasionalisme dengan dakwah bil qalam, yaitu jihad intelektual. Melalui jihad intelektual ia mampu melahirkan tokoh-tokoh nasional yang berperan penting pembentukan jati diri bangsa Indonesia. Pengaruhnya bagi nasionalisme santri di antaranya tampak dalam penerimaan NU terhadap Pancasila dan resolusi jihad yang dikeluarkan KH. Hasyim Asy'ari. Ini menunjukkan bahwa dakwah bil qalam mampu menjadi salah satu basis bagi penguatan nasionalisme.

Oleh karena itu, penulis merekomendasikan bahwa dalam upaya penguatan nasionalisme, dakwah bi qalam berbasis pesantren sangat penting digalakkan. Pemikiranpemikiran figh ulama klasik yang diajarkan dunia pesantren harus dihidupkan di tengah masyarakat. Pesantren dengan tradisinya yang khas dan materi kajiannya yang fleksibel yang menghargai perbedaan pendapat dapat menjadi basis nilai toleransi yang luar biasa berharga bagi masyarakat. Rekomendasi ini bukan tanpa alasan. Pesantren adalah lembaga pendidikan dan dakwah yang menyatu dengan kehidupan sosial masyarakat.

\section{DAFTAR PUSTAKA}

ACDP. (2017). Pesantren Contributes to Nurturing Nationalism.

Alfi, I. (2020). Strategi Pesantren dalam Pemberdayaan Masyarakat pada Era Generasi 4.0. MATAN: Journal of Islam and Muslim Society, 2.

Azra, Afriyanti, \& Hefner, A. D. R. W. (2020). Pesantren and Madrasa: Muslims School and National Ideals in Indonesia.

Azra, A. (2015). Islam dan Konsep Negara: Pergulatan Politik Indonesia Pasca-Soeharto. In M. A. D. dan A. F. F. Wawan Gunawan Abd. Wahid (Ed.), Fikih Kebinekaan: Pandangan Islam Indonesia tentang Umat, Kewarganegaraan, dan Kepemipinan Non Muslim. Bandung: PT. Mizan Pustaka.

Bruinessen, V. M. (1991). Kitab Kuning Pesantren dan Tarekat. Bandung: Mizan.

Dahlan, C. (1978). Sejarah Pujangga Islam Syekh Nawawi al-Bantani (1st ed.). Jakarta: CV Sarana Utama.

Dhofier, Z. (2011). Tradisi Pesantren. Jakarta: LP3ES.

Esposito, J. L. (2001). Makers of Contemporary Islam. New York: Oxford University Press.

Gobee, E. (1995). Snouck Hurgonje Semasa Kepegawaiannya Kepada Pemerintah Hindia Belanda 1889-1936. Jakarta: INIS XI.

Gufron, I. A. (2019). Santri dan Nasionalisme. Islamic Insights Journal, 1(1).

Hallaq, W. B. (1997). A History of Islamic Legal Theories: An Introduction to Sunni Usul al-Fiqh. Cambridge: Cambridge University Press.

Halwati, U., Alfi, I., \& Arifin, J. (2018). Nasionalisme di Tengah Pluralitas dan Kebebasan Pers. KOMUNIKA: Jurnal Dakwah Dan Komunikasi, 12(2), 329-354. 
KOMUNIKA: Jurnal Dakwah dan Komunikasi, 14 (1), April 2020

Adeni; Silviatul Hasanah (Kontribusi Dakwah Bil Qalam Syaikh Nawawi Al-Bantani...)

Hanan, A. (n.d.). Putting the Nationalism of Devout Indonesian Muslim Students in Doubt.

Hefner, R. (2000). Civil Islam: Muslims and Democratization. Princeton UniversityPress.

Ibrahim, A. (1989). Islam di Asia Tenggara Perspektif Sejarah. Jakarta: LP3ES.

Kafrawi. (1978). Pembaruan Sistem Pendidikan Pondok Pesantren. Jakarta: Cemara Indah.

Karel, S. (1984). Beberapa Aspek Tentang Islam di Indonesia Abad ke-19. Jakarta: Bulan Bintang.

Khalil 'Abd al-Karim. (1990). al-Judhur al-Tarikhiyya li al-Shari'a al-Islamiyya. Kairo: Sinaa li alNashr.

Lord, C. (2016). Between Islam and the nation; nation-building, the ulama and Alevi identity in Turkey. Journal of the Association for the Study of Ethnicity and Nationalism.

Lukens-Bull, R. (2005). A Peaceful Jihad: Negotiating Identity and Modernity in Muslim Java. New York: Palgrave Macmillan.

Madjid, N. (1995). Islam Agama dan Kemanusiaan: Membangun Tradisi dan Visi Baru Islam Indonesia. Jakarta: Paramadina.

Madjid, N. (1997). Bilik-bilik Pesantren: Sebuah Potret Perjalanan. Jakarta: Paramadina.

Mas'ud, A. (2006). Dari Haramain ke Nusantara: Jejak Intelektual Arsitek Pesantren (1st ed.). Jakarta: Prenada Media Group.

Mastuhu. (1994). Dinamika Sistem Pendidikan Pesantren. Jakarta: INIS.

Muhammad, A. (2015). Pesantren, Kemerdekaan dan Keindonesiaan.

Mustafid, M. (2012). Seminar Toleransi Kebangsaan; Membumikan NilaiNilai Kerukunan dalam Konteks Keindonesiaan.

Nawawi, M. (n.d.-a). al-Futuhat al-Madaniyyah dalam Hamisyh Nasaih al-Ibad. al-Haramain.

Nawawi, M. (n.d.-b). Kasyifah al-Saja. Semarang: Matba'ah Usaha Keluarga.

Nawawi, M. (n.d.-c). Tanqih al-Qaul al-Hasis. Semarang: Matba'ah Usaha Keluarga.

Nawawi, M. (n.d.-d). Tawsyaikh ibn Qasim al-Guzzi Qut al-Habib al-Gharib. Surabaya.

Nisa \& Mahbib, D. K. (2013). Peran Pesantren dalam Menegakkan Nilai Toleransi.

Rafiudin, R. (n.d.). Sejarah Hidup dan Silsilah Syekh Nawawi Al- Bantani. Serang: Yayasan Syekh Nawawi Al-Bantani.

Reza Fahmi Haji Abdurrachim. (2016). Islamic Fundamentalist and Nationalism (Study At Darul Ma'rifat Islamic Boarding School, Kediri - East Java). Journal of Islamic and Social Studies, 2(1). https://doi.org/http://dx.doi.org/10.30983/islam_realitas.v2i1.113

Ronika, Rima, Mukhtasar Syamsuddin, \& A. K. (2019). Religiosity Value as Indonesian Nationalism (Study of Nahdlatul Ulama Multipurpose Ansor Brigade). Research, Society and Development, Itabira, 8(7).

Roy, O. (n.d.). Islamism and Nationalism. Le Seuil, 1(104), 45-53. https://doi.org/10.3917/ pouv.104.0045

Sahmawi, Fanani, \& Nuh, Z. M. (2018). Sahmawi, Fanani, Z., M. Nuh (2018). The Strategic Role of Islamic Boarding School on Instilling Nationalism Values in Al-Hikmah and Miftahul Huda Malang East Java Indonesia. International Journal of Scientific and Research Publications, 8(8). https://doi.org/10.29322/ijsrp.8.8.2018.p8022

Shabana, A. (2010). Custom in Islamic Law and Legal Theory: The Development of the Concepts of 'Urf and 'Aadah in the Islamic Legal Tradition. New York: Palgrave Macmillan.

Shihab, Q. (1995). Membumikan al-Quran. Bandung: Mizan. 
KOMUNIKA: Jurnal Dakwah dan Komunikasi, 14 (1), April 2020

Adeni; Silviatul Hasanah (Kontribusi Dakwah Bil Qalam Syaikh Nawawi Al-Bantani...)

Shobirin, M. (2018). Pesantren, Nationalism and Integration. RISEA (Review Journal of Southeast Asia), 1(1), 110-129.

Suprtano, H. (2019). Multicultural Education for Cultivating Nationalism and Preventing Radicalism of Santri in Pesantren. Research on Humanities and Social Sciences, 9(20). https:// doi.org/10.7176/RHSS/9-20-03

Vandenbosh, A. (1995). Nationalism and Religion in Indonesia. Far Eastern Survey, 21(18), 181-185.

Wahid, D. (2014). Nurturing Salaf Manhaj: A Study of Salaf Pesantrens in Contemporary Indonesia. Utrecht University.

Winet, E. D. (2009). Between Umat and Rakyat: Islam and Nationalism in Indonesian Modern Theatre. Theatre Journal, 61(1), 43-64.

Wolters, O. . (1998). Southeast Asia as A Southeast Asian Field of Study. Indonesia, 58.

Woodward, M. (2011). Java, Indonesia and Islam. New York: Springer.

Zuhdi, M. (2018). Challenging Moderate Muslims: Indonesia's Muslim Schools in the Midst of Religious Conservatism. Religions, 9(10), 310. https://doi.org/https://doi.org/10.3390/ rel9100310 